\title{
Trypanorhynchid cestodes of commercial inshore fishes of the West African coast
}

\author{
Harry Palm ${ }^{(1)}$, Austin Obiekezie ${ }^{(2)}$ and Heino Möller (1) \\ (1) Institut für Meereskunde an der Universität Kiel, Düsternbrooker Weg 20, D-24105 Kiel, Germany. \\ (2) Insitute of Oceanography, University of Calabar, PMB 1115, Calabar, Nigeria. \\ Received January 4, 1994; accepted February 18, 1994.
}

Palm H., A. Obiekezie, H. Möller, Aquat. Living Resour., 1994, 7, 153-164.

Résumé

\begin{abstract}
A wide spectrum of fish hosts in the Gulf of Guinea was examined for infestation with trypanorhynchid cestodes. A total of 1341 specimens belonging to 45 species were examined. The following 9 trypanorhynchid species were identified: Callitetrarhynchus gracilis, Grillotia perelica, Nybelinia sp., Otobothrium cysticum, O. dipsacum, Otobothrium sp., Poecilancistrum caryophyllum, Ptero-bothrium sp. and one unidentified species. The pattern of occurrence of Callitetrarhynchus gracilis has been used to draw conclusions on a possible 4-host life cycle of the species, involving two obligatory teleost host fish species, small clupeids and large predatory fish. The most abundant parasite was $O$. cysticum which was found in 8 host fishes. In general most other species occurred in one host fish species only. The study confirms the predominance of otobothriid cestodes in the parasite fauna of tropical and subtropical teleost fish species. Since only Pseudotolithus senegalensis and Stromateus fiatola harboured flesh infestations, trypanorhynchids do not pose serious dangers to the marketability of most commercially important fish species in the area. The method of scanning electron microscopy was used to clarify the details of hooklet arrangement on the tentacular armature of some species for the first time.
\end{abstract}

Keywords : Gulf of Guinea, Trypanorhyncha, commercial fish, food hygiene, parasite, cestode, life cycle.

Cestodes Trypanorhynches larvaires parasites de poissons côtiers commerciaux de la côte ouest africaine.

Un large spectre de poissons du golfe de Guinée a été étudié pour déterminer l'importance du parasitisme par les larves de Cestodes Trypanorhynches. Au total 1341 individus, appartenant à 45 espèces, ont été examinés. Neuf Trypanorhynches ont pu être identifiés: Callitetrarhynchus gracilis, Grillotia perelica, Nybelinia sp., Otobothrium cysticum, $O$. dipsacum, Otobothrium sp., Poecilancistrum caryophyllum, Pterobothrium sp. et une espèce non identifiée. La fréquence de Callitetrarhynchus gracilis a été utilisée pour conclure à l'existence pour cette espèce d'un cycle biologique à 4 hôtes dont, comme hôtes obligatoires, deux Téléostéens, de petits Clupéidés et de grands poissons prédateurs. Le parasite le plus abondant $O$. cysticum a été trouvé dans 8 espèces de poissons hôtes; la plupart des autres parasites l'ont été dans une seule espèce de poisson. Cette étude confirme la prédominance des larves d'Otobothiidés dans la faune des Cestodes parasites des Téléostéens tropicaux et sub-tropicaux. Du fait que, seuls Pseudotolithus senegalensis et Stromateus fuatola ont été trouvés porteurs dans leur chair de larves de Trypanorhynches, il résulte que ces Cestodes ne posent pas de sérieux dangers dans la commercialisation de la plupart des autres poissons étudiés. La microscopie électronique à balayage été utilisée pour la première fois chez plusieurs de ces Trypanorhynches pour mettre en évidence la disposition des crochets des trompes et les détails de leur morphologie.

Mots-clés : Golfe de Guinée, Cestodes, Trypanorhynches, parasites, cycle biologique, poissons commerciaux. 


\section{INTRODUCTION}

Trypanorhynch cestodes infesting elasmobranchs as final hosts may use teleost fishes as intermediate or paratenic hosts. Although only a few cases of accidental human infestations have been reported (Bates, 1990), their infestation of the body cavity and the musculature of fishes may present marketing problems for commercially exploited species (Petersen et al., 1993). For instance, heavy infestation of the Alaska pollack Theragra chalcogramma with plerocercoids of Nybelinia surmenicola have reduced the consumable part of the fish to the dorsal musculature (Grabda, 1977). Similarly, infestation with plerocercoids of Gymnorhynchus thyrsitae has seriously affected the exploitation of the highly valued Thyrsites atun in New Zealand (Mehl, 1970).

The complement of larval helminth infestations of commercial fish species of temperate waters is fairly well known as a result of the highly developed fishing industry. The most important commercial species of the North Atlantic, such as Clupea harengus, Gadus morhua, Hippoglossus hippoglossus, Reinhardtius hippoglossoides, Sebastes fasciatus and S. marinus have been particularly well studied in this regard (Dollfus, 1953; Hemmingsen and MacKenzie, 1993; Lüling, 1951; MacKenzie, 1987; Scott, 1988; Scott and Bray, 1989). The checklist of Bates (1990) shows a preponderance of trypanorhynchid cestodes in fishes from the northern part of the Atlantic which most probably reflects the number of investigations rather than the true geographical distribution of the species. On the other hand, reports on fish cestodes of the South East Atlantic are scarce. Particularly from the gulf of Guinea the only published records are those of Bane (1969), Baudin-Laurencin (1971), Bussieras and Aldrin (1965), Reimer (1984) and Obiekezie et al. (1992), all of which are essentially isolated observations on single or a limited number of species.

The increasing exploitation of West African marine inshore fishes for foreign markets requires a thorough understanding of their pathology so as to meet the necessary standards of quality. This study represents the first large-scale investigation of a wide fishhost range in order to determine the spectrum of larval cestodes from a typical West African inshore location. Such data permit regional comparisons and a more effective discussion of the zoogeography of larval cestodes. Particular attention was given to those cestodes which occur in the musculature or have the capability to invade it thereby producing marketing or public health problems. In addition to the establishment of several new host and locality records, the methods of scanning electron microscopy have been used as proposed by Palm et al. (1993) for a more accurate documentation of the tentacular hooklet structure of some of the species which hitherto have not been satisfactorily described.

\section{MATERIAL AND METHODS}

At different times between 1988 and 1990, a total of 1121 fish specimens from 45 species and 27 families were examined for trypanorhynch cestodes in their flesh. 776 fish from the same sample were examined for plerocercoids in the stomach wall, intestine wall, mesenteries and the body cavity. In late 1991, an additional sample of 120 commercially highly valuable tongue soles (Cynoglossus senegalensis) and 100 schooling pelagic clupeids (Ethmalosa fimbriata) were examined for both flesh and viscera infesting cestodes. Fish samples were landed by commercial bottom trawlers and traditional artisanal fishermen operating in the rich fishing grounds on the western shore of the Cross River estuary (East Nigeria) between $8^{\circ} 10^{\prime}$ and $8^{\circ} 25^{\prime} \mathrm{E} ; 4^{\circ} 25^{\prime}$ and $4^{\circ} 35^{\prime} \mathrm{N}$ (fig. 1).

Fish were examined fresh or as deep frozen specimens which had been preserved for up to 10 days after capture. They were identified using the FAO identification sheets for the Eastern Central Atlantic (Fischer et al., 1981), and data were taken on individual sex, length and weight of the samples. Body cavity, gastro-intestinal tract and internal organs were searched with the help of a stereo-microscope under 6x magnification for the presence of metacestodes. For determination of musculature infestations, thin fillets were pressed between two acrylic glass plates to a thickness of 3 to $5 \mathrm{~mm}$ and examined on a candling table over a fluorescent light source. The dark and opaque cysts of the parasites were easily distinguishable against the transparent background of the muscle fibres.

For scanning electron microscopy (SEM) which was used to study the tentacular armature of some of the species, specimens were fixed in $2.5 \%$ glutaraldehyde, dehydrated in an alcohol series, air dried and sputtered with gold-palladium in an argon atmosphere at $1.2 \mathrm{kV} / 40 \mathrm{~mA}$. Observations were made using a Joel JSM-35C scanning electron microscope at $15 \mathrm{kV}$. Material for the SEM of Otobothrium dipsacum was obtained from the North East Brazilian coast.

In the taxonomic sections of this paper, the following abbreviations are used for the different body regions of the metacestodes: pars bothridialis (pbo), pars vaginalis ( $p v)$, pars bulbosa $(p b)$ and appendix (app.). All measurements are given in micrometers unless otherwise indicated.

\section{RESULTS}

Nine different trypanorhynchids were encountered; tetraphyllid and pseudophyllid plerocercoids could not be isolated. Their various hosts and sites of infestation are listed in table 1. Except of Callitetrarhynchus gracilis, Otobothrium cysticum and Otobothrium sp., the rest represent first records for their hosts and for the gulf of Guinea. Most of the trypanorhynchids occurred in the body cavity and the mesenteries. Musculature 


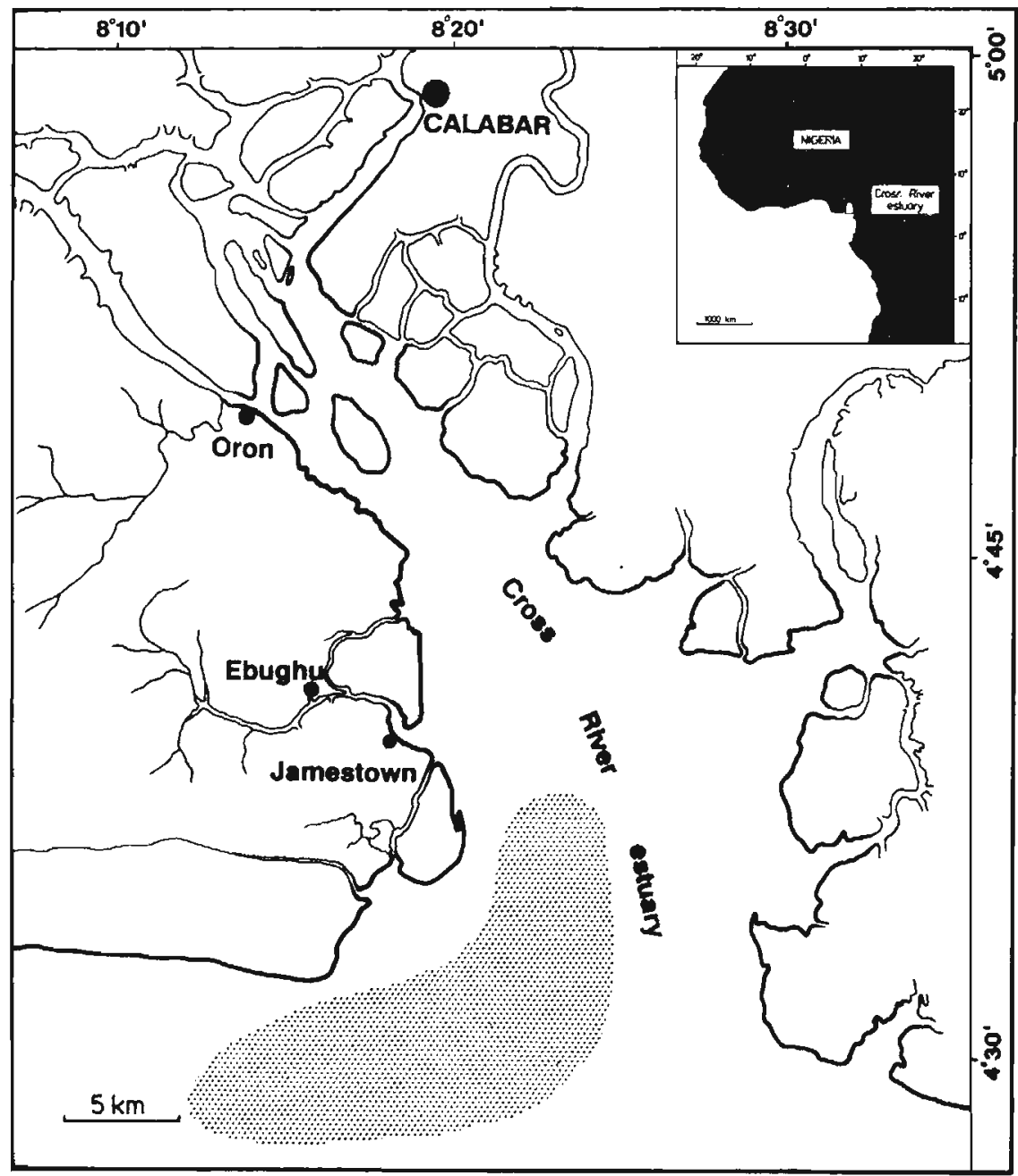

Figure 1. - Map showing fishing grounds in the Cross River estuary (stippled area).

infestation was recorded for Otobothrium sp. in Stromateus fiatola and Poecilancistrum caryophyllum in Pseudotolithus senegalensis. Remarks on the individual species isolated, particularly on their taxonomy, zoogeography and capability to invade the fish flesh, are presented below.

\section{Fam. Tentaculariidae}

\section{Nybelinia sp.}

One specimen of this parasite was found encapsulated in the stomach wall of a Pomadasys peroteti. The scolex measured $1300 \mu \mathrm{m}$ in total length and showed the typical four bothridia with thickened margins. The following measurements were taken: $p b o=550$, $p v=400, p b=300, a p p=400$. The homeoacanthous armature consists of small sized (10 high) hooklets with 6 to 7 hooks each half turn. The size of hooks on external and internal surface is similar and no specific basal armature is visible. So far 19 species of the genus Nybelinia have been reported from teleost fishes of the Atlantic (Palm, 1992). Of these Dollfus (1960) enumerated 13 species from the North West African coast among which Nybelinia dakari and $N$. estigmena fall into the same size range and show similar tentacular armature to the present specimen. A definite identification could not be made due to lack of sufficient material. Both species have been reported only from that locality and the present finding implies an extension of their range.

Plerocercoids of Nybelinia species often infest the stomach or the stomach wall of several marine teleosts. The low abundance of Nybelinia sp. in Pomadasys peroteti as well as the limited potential of most Nybelinia species to invade the fish flesh imply a low probability of finding parasites of this genus in the musculature of fishes from the gulf of Guinea. 
Tais 1. - Occurrence of cestodes in commercial fish species from the Nigerian coast (n.i. = not irfested).

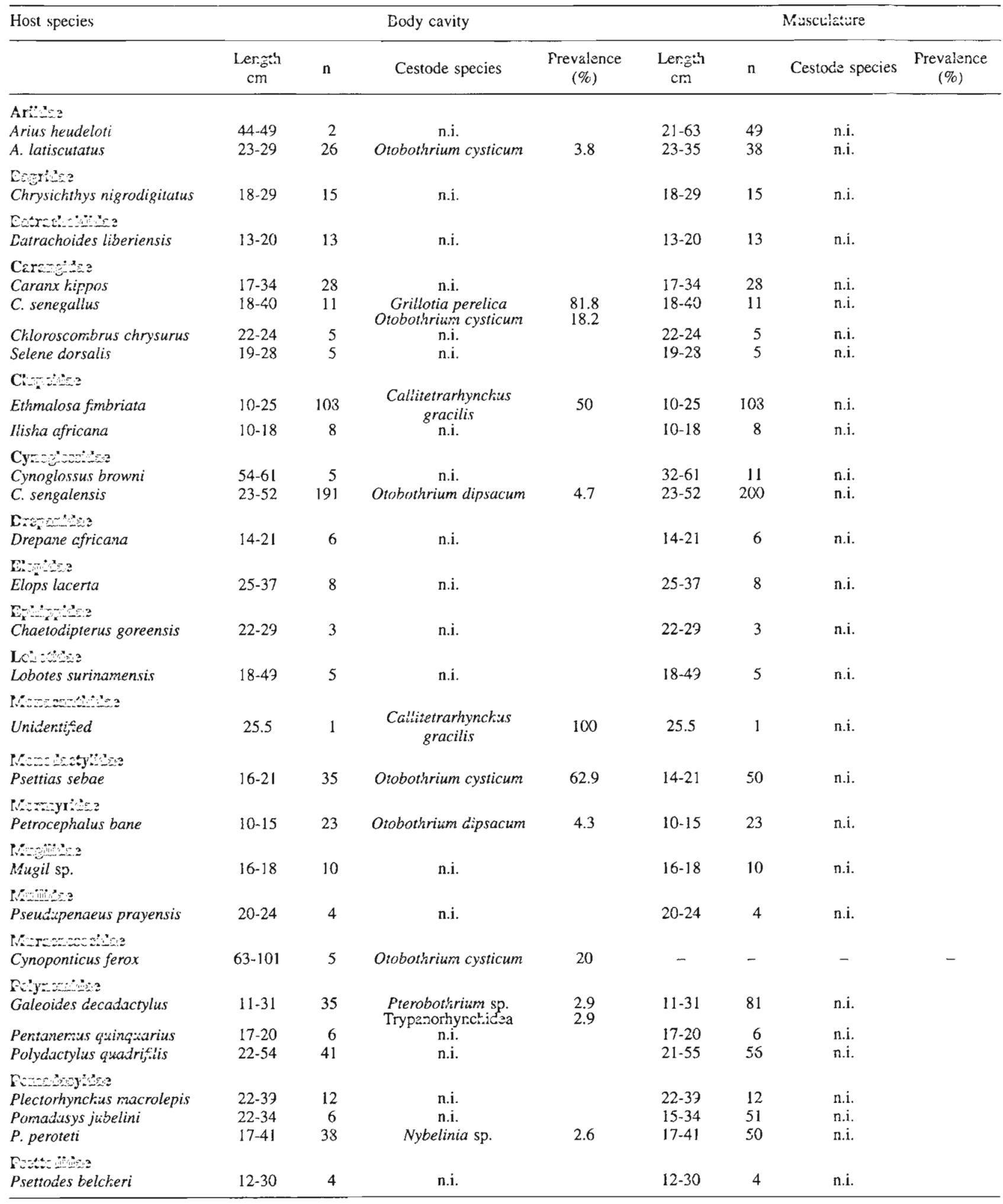


Table 1. - To be continued.

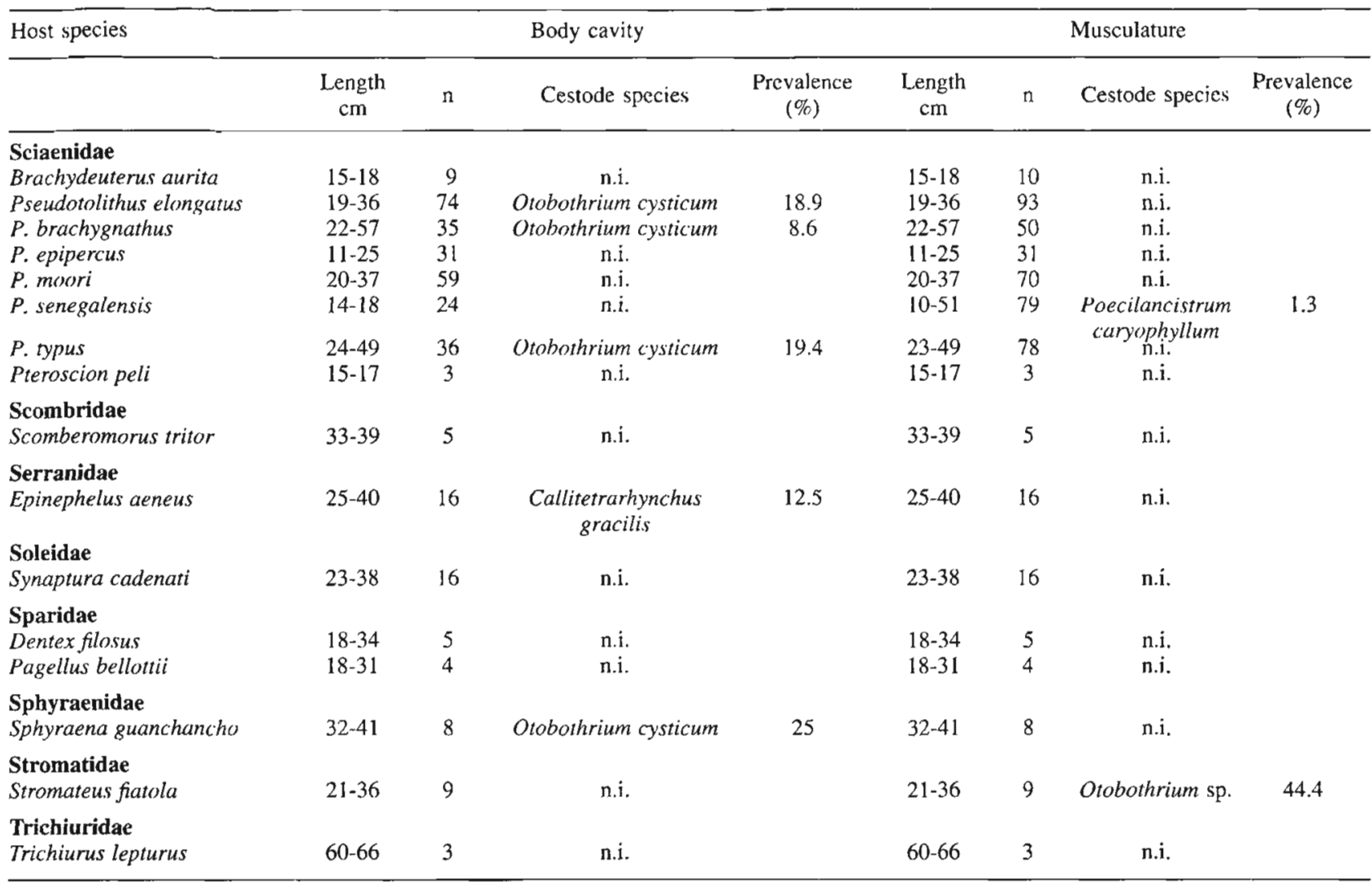

\section{Fam. Lacistorhynchidae}

\section{Callitetrarhynchus gracilis (Rudolphi, 1819)}

C. gracilis infested three fish species in two widely differing size forms. Small-sized plerocercoids (blastocysts, $1.5-7.0 \mathrm{~mm}$; scolex, $2.8 \mathrm{~mm}$ mean total length) were found only in the pelagic clupeid Ethmalosa fimbriata at a prevalence rate of $50 \%$. Larger forms (blastocyst, $1.3-1.9 \mathrm{~cm}$; scolex $1.5 \mathrm{~cm}$ mean total length) occurred in Epinephelus aeneus and an unidentified Monacanthidae. The morphological characteristics of the scolices agree with the descriptions of Dollfus (1942) and Carvajal and Rego (1985).

C. gracilis is cosmopolitan in tropical, subtropical and south temperate waters. Dollfus (1942) listed 55 teleost fishes as second intermediate hosts for the species. Records from the gulf of Guinea are those of Dollfus (1942) from Lutjanus goreensis and Bane (1969), Baudin-Laurencin (1971), Bussieras and Aldrin (1965) from the yellowfin tuna, Thunnus albacores, which are both generally large predatory fishes. The occurrence in Ethmalosa fimbriati in a distinctly smaller size form represents a new record in this pelagic clupeid.

\section{Fam. Grillotiidae}

Grillotia perelica (Shuler, 1938)

Plerocercoids of $G$. perelica were highly host and organ specific to the swim bladder of Caranx senegallus (fig. 2). The results show a direct relationship between host length and numbers of the cestode, the largest individuals $(<30 \mathrm{~cm})$ harbouring up to 100 plerocercoids in the swim bladder. Histological sections of the kidney in heavily infested fish showed extreme cellular infiltration which indicated a strong host response.

G. perelica was first described as Tentacularia perelica by Shuler (1938) from the spiral valve of the lemon shark, Hypoprion brevirostris, from the North West Atlantic. Dollfus (1942) placed it within the genus Grillotia and gave a more detailed description of the tentacular armature. Scanning electron micrographs (fig. $2 c-e$ ), however, show some hitherto unidentified features of hooklet morphology and arrangement. The row of small hooks on the external surface, typical for the poeciloacanthous armature, ends in a field of small hooks which is limited by a group of horizontally inserted hooks with rounded tips (fig. $2 e$ ). This is a third type of hook tip beside the normal spiny and 

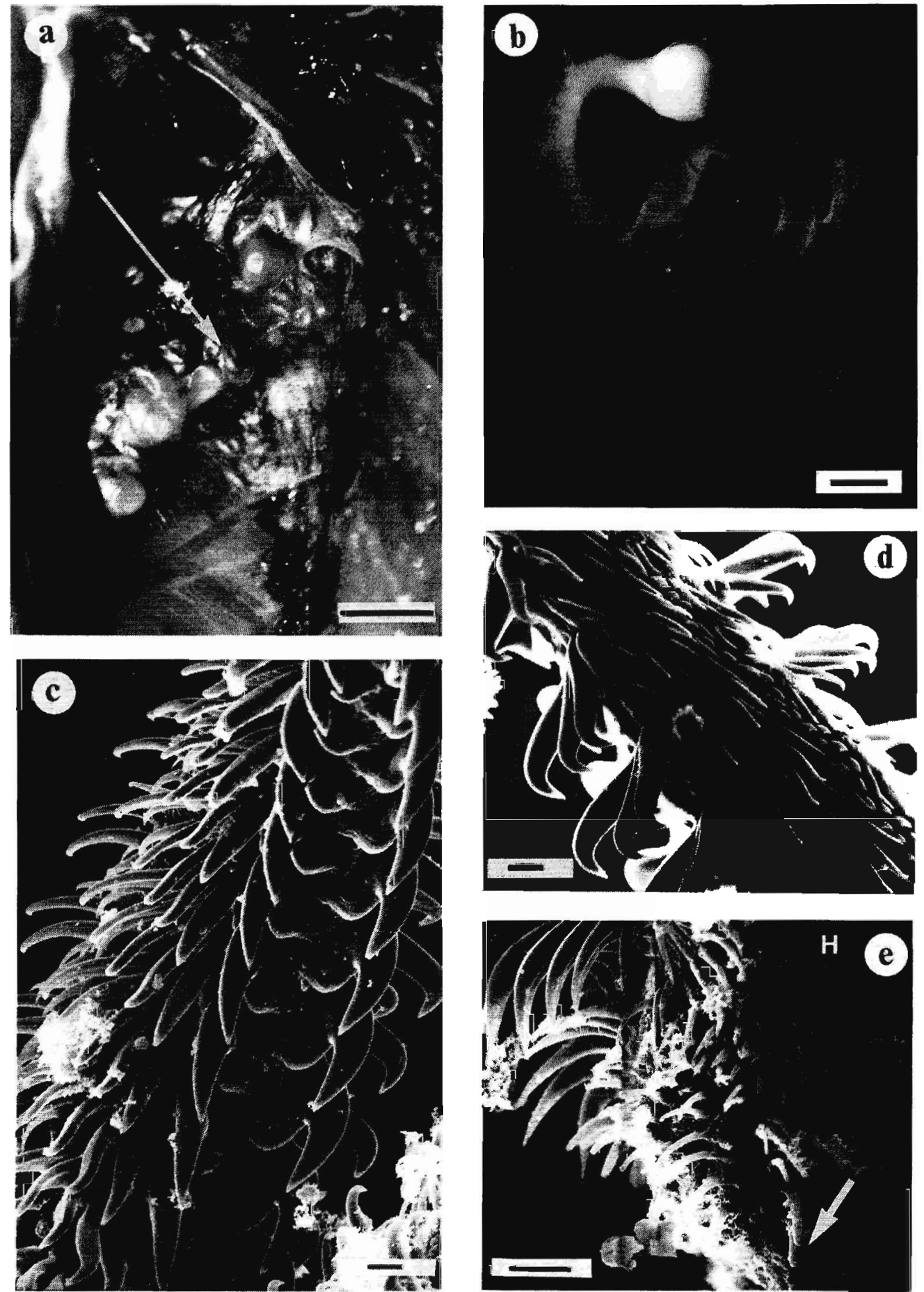

Figure 2. - Grillotia perelica from Caranx senegallus. a) Mass of plerocercoids in the swim bladder ( $(\mathrm{scale}$ bar $=1 \mathrm{~cm}) ; b$ ) Isolated worm like plerocercoid (scale bar $=1 \mathrm{~mm}$ ); c) Metabasal armature on internal tentacle surface (scale bar $=10 \mu \mathrm{m}$ ); $d$ ) Row of small hooklets on external tentacle surface (scale bar $=10 \mu \mathrm{m}$ ); e) Basal armature on external surface: cluster of small hooklets $(\mathrm{H})$ terminating in forms with rounded apices (scale bar $=10 \mu \mathrm{m}$ ).

bifid forms known from Callitetrarhynchus gracilis (Palm, 1992) and Pterobothrium acanthotruncatum (Escalante and Carvajal, 1984). On the internal surface no specifically formed hooks were visible.
Long after the description of the adult stage, plerocercoids of $G$. perelica were found for the first time in the musculature of Mugilidae from the South East African coast (Schramm, 1991). The present report 
represents the second observation of this remarkable metacestode in a new host but with different organ preferences. Like other trypanorhynchids $G$. perelica has the potential to invade different habitats in its hosts. It seems that in some Trypanorhynchidea, site of infestation in the second intermediate host not only depends on the cestode species but also is dependent on host fish and locality.

\section{Fam. Otobothriidae}

\section{Otobothrium cysticum (Mayer, 1842)}

This was the most frequently occurring trypanorhynchid cestode with the widest host range. Eight out of the 45 fish species examined harboured $O$. cysticum. Prevalence of infestation varied between $4 \%$ in Arius latiscutatus and $63 \%$ in Psettias sebae (table 1). Connective tissue capsules were found near the stomach and the intestine which harboured the blastocyst within the scolex was embedded in a fatty covering (fig. $3 a$ ). Morphological characteristics of the scolex agree with the description of $O$. cysticum from Dentex macrophthalmus by Dollfus (1942). Scanning electron micrographs of the armature (fig. $3 b-d$ ) show the typical heteroacanthous arrangement of hooklets particularly in the basal region. $O$. cysticum is widely distributed along the West African coast (Dollfus, 1942). The present results greatly extend the host range for the species.

Several otobothriid species are known to invade the flesh of fish, although this could not be demonstrated for $O$. cysticum during this study in spite of its wide host range.

\section{Otobothrium dipsacum (Linton, 1897)}

$O$. dipsacum was isolated from the mesenteries of the freshwater fish Petrocephalus bane and the tongue sole Cynoglossus senegalensis at a prevalence rate of 4 and $5 \%$ respectively (fig. $4 a$ ). Neither the original description by Linton (1897) nor those of later authors (Southwell, 1929; Cruz-Reyes, 1973) contain sufficient details of the tentacular armature. We present scanning electron micrographs using material from the North East Brazilian coast which show the remarkable arrangement of the tentacular hooklets (fig. $4 b-d$ ). The internal surface is covered with 5-6 slender, rose-thorn shaped hooks closely arranged in definite calary rows (fig. $4 b$ ). On the bothridial and antibothridial surfaces up to 10 similar hooks diminishing in size graduate into rows of 30 to 35 smaller hooks on the external surface (fig. $4 c-d$ ).

$O$. dipsacum has been recorded earlier from the North West Atlantic, gulf of Mexico and Indian Ocean (Cruz-Reyes, 1973). The present findings represent the first record of the species from the West African and the North East Brazilian coast. $O$. dipsacum seems to have a world wide distribution in tropical and subtropical waters, using several teleost fish species as second intermediate hosts in the different localities. Although the site of infestation has always been reported to be the body cavity and the mesentery, 6 Otobothrium sp. isolated from the flesh of Otoperca aurita and Polynemus quadrifiliis in the Congo were assigned to $O$. dipsacum by Dollfus (1942).

\section{Fam. Pterobothriidae}

\section{Pterobothrium sp.}

The scolex measurements of two specimens of a Pterobothrium sp. from the mesenteries of a Galeoides decadactylus were as follows: total length $=2650 \mu \mathrm{m}$, $p b o=600, p v=1000, p b=1250$. The heteroacanthous armature consisted of rows of 4 calary hooks (30-50) on the internal and bothridial (antibothridial) surfaces and rows of small hooks (5-8) on the external surface. Dollfus (1942) listed 8 species of Pterobothrium mostly from tropical and subtropical parts of the world ocean. Of these Pterobothrium heteracanthum is known to invade the fish flesh of various host fish species (Overstreet, 1977; Reimer, 1984) whereas other known species mainly infest the viscera and the internal organs.

\section{Trypanorhynchidea (not further identified)}

Out of a Galeoides decadactylus one $7 \mathrm{~mm}$ long blastocyst of an unidentified trypanorhynchid cestode was isolated from the mesenteries. It contained a $1.5 \mathrm{~mm}$ long scolex with 4 bothridia and a short pars bulbosa. On the basis of these characteristics the parasite could be assigned to the Gilquiniidae.

Two other otobothriid species have been reported in a previous communication from the same area (Obiekezie et al., 1992). Two plerocercoids of Poecilancistrum caryophyllum were isolated from the musculature of 1 out of 79 Pseudotolithus senegalensis examined. This cosmopolitan, musculature-invading parasite mainly infests sciaenids as reported for the gulf of Mexico by Overstreet $(1977 ; 1978)$. However, the infestation rate observed in the gulf of Guinea was much lower than in other geographical regions. Another fish species, Stromateus fiatola, was heavily infested whith an Otobothrium sp. They were distributed throughout the musculature and between the vertebrae. Four of the 9 fish investigated were found to be infested with this trypanorhynchid in their flesh, which has been reported earlier from the same host in Senegal by Reimer (1984). It could be concluded that along the entire West African coast, Stromateus fiatola is similarly heavily infested with Otobothrium sp.

\section{DISCUSSION}

This study, which for the first time provides information on the spectrum of trypanorhynch infestations of commercially exploited inshore teleost 

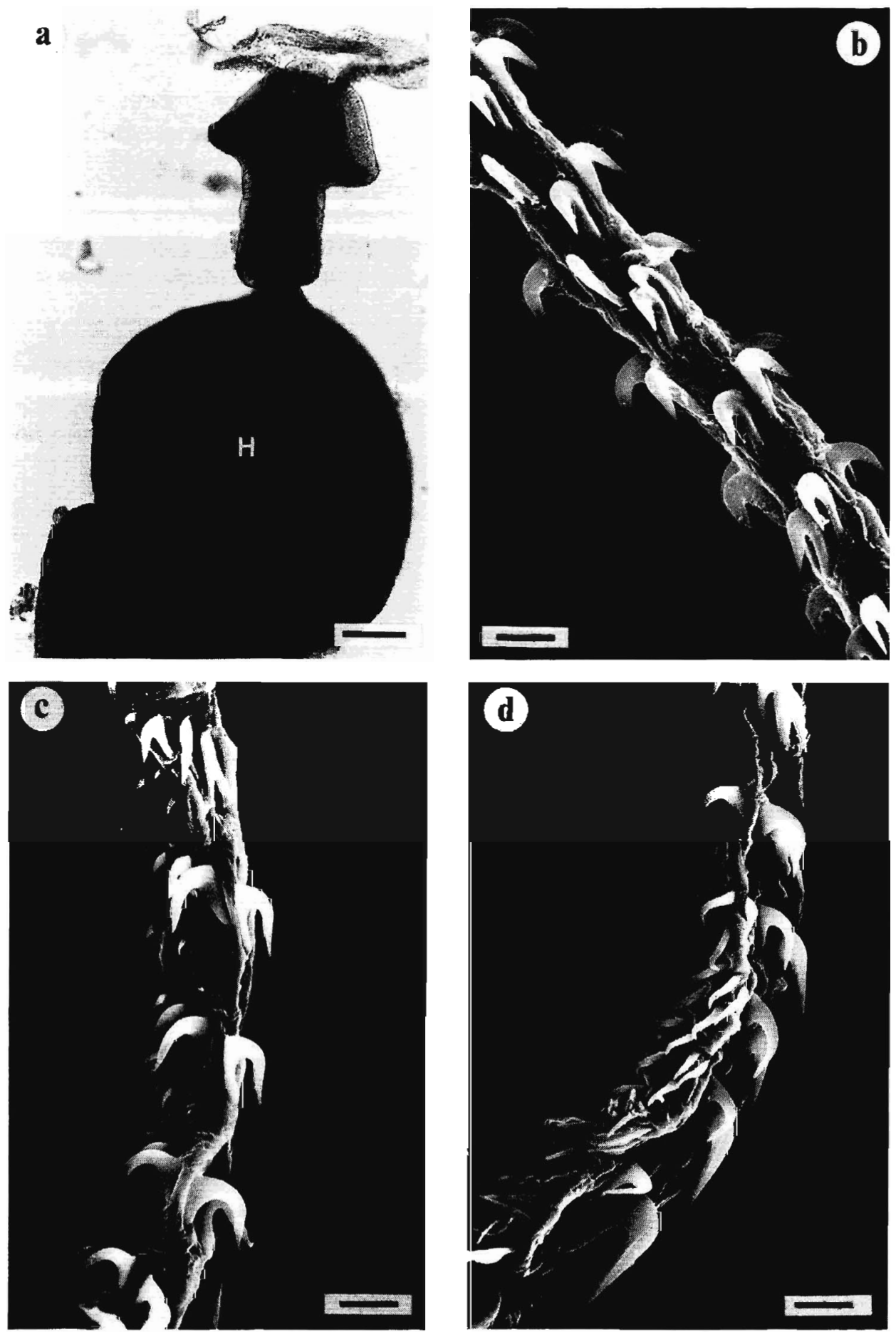

Figure 3. - Otobothrium cysticum from Pseudotolithus elongatus, a) Scolex still attached to its fatty covering (H) (scale bar $=100 \mu \mathrm{m}$ ); $b$ ) SEM of metabasal tentacular armature: internal surface (scale bar $=5 \mu \mathrm{m}) ; c)$ SEM of basal tentacular armature: internal surface (scale bar $=5 \mu \mathrm{m})$; d) SEM of basal tentacular armature: bothridial surface (scale bar $=5 \mu \mathrm{m}$ ).

fishes of the gulf of Guinea, complements previous isolated data from this locality. 17 host and 7 locality records have been established. The diversity of the cestode fauna is comparable to the situation in some other tropical areas, such as gulf of Mexico (Overstreet, 1977; 1978) or the East coast 

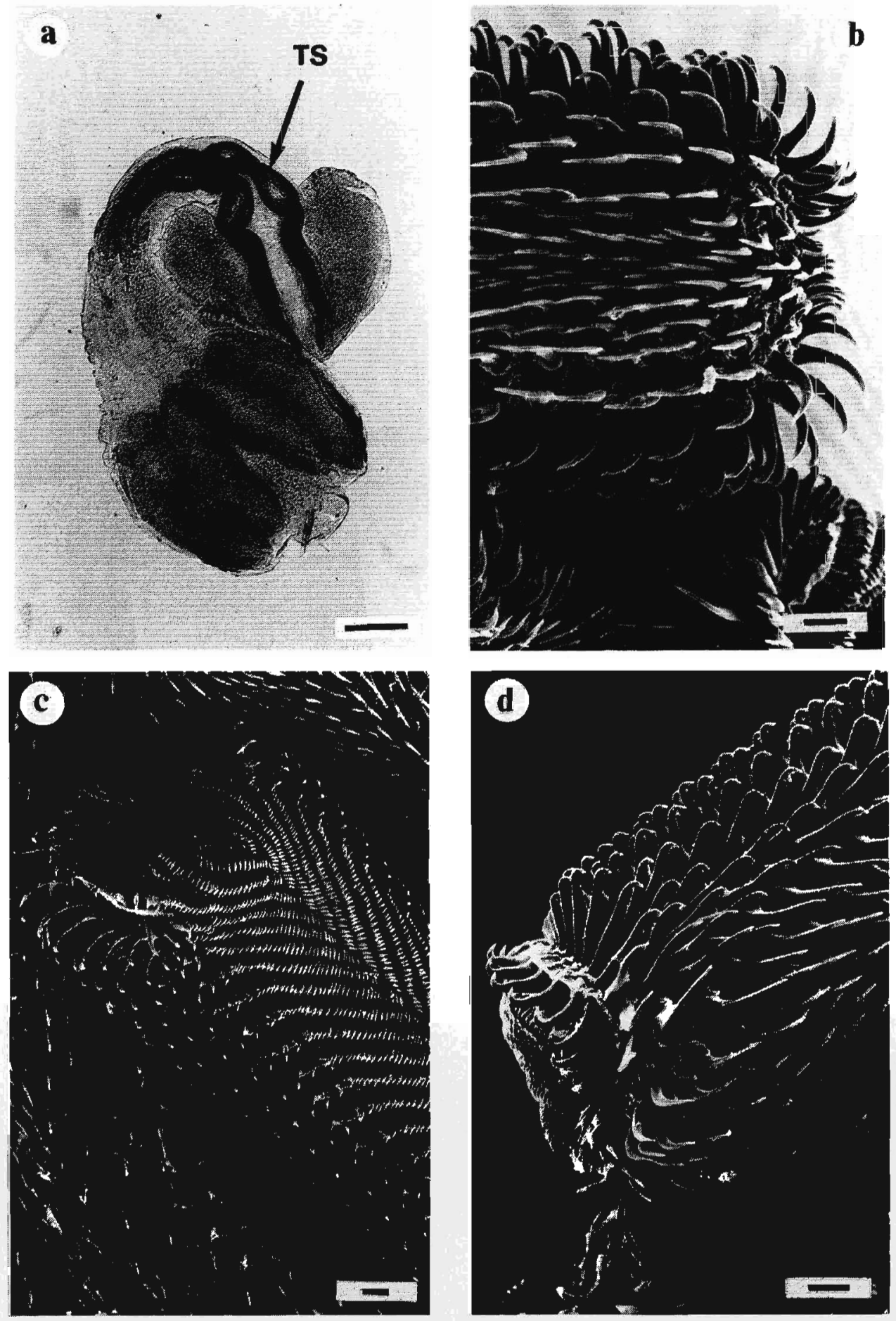

Figure 4. - Otobothrium dipsacum from Pseudupeneus maculatus. a) Scolex: the two bothridia, bulbs and tentacle sheats (TS) are clearly visible (scale bar $=250 \mu \mathrm{m}) ; b$ ) Metabasal armature on internal tentacle surface (scale bar $=10 \mu \mathrm{m}$ ); $c$ ) Metabasal armature on external tentacle surface (scale bar $=10 \mu \mathrm{m}$ ); d) Metabasal armature on bothridial tentacle surface (scale bar $=10 \mu \mathrm{m}$ ).

of India (Southwell, 1929). Only members of the order Trypanorhynchidea were encountered including several cosmopolitan species, while the Tetraphyllidea, which are presumed to be more localized in distribution, were not found. The diverse and abundant elasmobranch fauna of the gulf of Guinea accounts for 
the preponderance of the trypanorhynch for which they serve as final hosts. The absence of plerocercoids of the Pseudophyllidea is in agreement with the known distribution of the order which occurs mainly in the boreal and arctic regions in relation to the distribution of their final hosts.

Taking into account the report of Dasyrhynchus talismani by Baudin-Laurencin (1971), 4 out of 10 trypanorhynchid cestodes known from teleost fishes fo the gulf of Guinea belong to the family Otobothriidae. Results from the gulf of Mexico show a similar predominance of this family in the teleost fishes. Otobothriids are apparently dominant trypanorhynchids of tropical and subtropical waters, which is noteworthy in view of the propensity of this group to penetrate and inhabit fish flesh.

Most of the cestodes had a narrow host range, infesting only one or two second intermediate hosts. Within this category are Grillotia perelica, Nybelinia sp., Otobothrium dipsacum, Otobothrium sp., Poecilancistrum caryophyllum and Pterobothrium sp. Of these Grillotia perelica, Otobothrium dipsacum and Poecilancistrum caryophyllum infest several different intermediate hosts in other geographical regions (Cruz-Reyes, 1973; Overstreet, 1977; 1978; Schramm, 1991). Otobothrium cysticum on the other hand is characterized by a lack of host specificity in the gulf of Guinea, occurring in 8 of 19 fish species infested with trypanorhynch cestodes. This assures the maintenance of its population in the locality within the final hosts. Apparently this cestode either uses one very predominant first intermediate host or a wide range of such hosts to gain such effective access to the food chain. It would seem that trypanorhynch cestodes potentially are able to infest a wide range of teleosts as second intermediate hosts. Their success in this regard, however, depends on the presence of the first intermediate hosts within the particular localities. Such a dependency in the occurrence of cosmopolitan parasite species on the first intermediate hosts has been demonstrated recently for the anisakid nematode Contracaecum osculatum in the high Antarctic food web (Klöser et al., 1992).

Callitetrarhynchus gracilis is a widely distributed trypanorhynch with a continually increasing host range. As reported during this study, the plerocercoids also occur in two distinct size forms at the North East Brazilian coast (Palm, 1992) - the small form in two clupeids (Harengula clupeola, Opisthonema oglinum) and a carangid (Caranx chrysos), the large form in two carangids (Oligoplites palometa, Selene vomer) and the scombrid Scomberomorus maculatus. Mattis (1986) proposed a four-stage life cycle for Poecilancistrum caryophyllum, requiring two fish intermediate hosts to complete its life cycle. As typical for trypanorhynchid cestodes, this species develops a procercoid or primary metacestode out of an oncospere in a copepod. The author assumed a secondary metacestode lacking a developed scolex in the viscera of a copepod-eating teleost. The fully developed plerocercoid or terminal metacestode infests sciaenids. Similarly Nakajima and Egusa (1972) have indicated the possibility of a four-host life cycle for Callitetrarhynchus nipponica although the first intermediate host was not found. Callitetrarhynchus gracilis has two very distinct growth potentials in its various hosts. Although the small scolices are fully developed, they might not be a scolex variation but an obligatory stage to complete the development of the species. It would seem that Callitetrarhynchus might require at least two obligatory teleost fish intermediate hosts. Unless experimental infestation studies have been carried out, we propose a four-host cycle for $C$. gracilis involving small pelagic Carangidae and Clupeidae harbouring the secondary metacestode which develops into the terminal metacestode stage in larger predatory fish, mostly Carangidae and Scombridae.

Pathogenic effects of larval cestodes on free-living host fish species are difficult to demonstrate. Although Hoffmann et al. (1986) are of the opinion that such influences may be diverse and include growth disturbances and lowering of the condition factor, direct pathogenic effects have been established in only a few cases (Radhakrishnan et al., 1983; Richards and Arme, 1981; Rosen and Dick, 1984). Adjei et al. (1986) attribute increased mortality of Saurida tumbil to the pressure on the ventral aorta exerted by the blastocyst of Callitetrarhynchus gracilis. Bussieras and Aldrin (1965) showed an increased mortality of young Thyrsites atun due to heavy infestation of the ventral aorta with plerocercoids of Dasyrhynchus talismani. Results from this study indicate that the swim bladder infestation of Caranx senegallus by Grillotia perelica must lead to altered weight and malfunction of the organ. It has been demonstrated that the swimming speed in fish may be greatly reduced by helminth infestation of the swim bladder or the musculature (Sprengel and Lüchtenberg, 1991). It can be expected that Caranx senegallus heavily infested with Grillotia perelica fall easier prey as a result of reduced swimming speed. This would greatly improve the chances of the parasite which is dependent on just one second intermediate host in this Jocality to reach the final host. The musculature infestation of Stromateus fiatola by Otobothrium sp. and Pseudotolithus senegalensis by Poecilancistrum caryophyllum may have similar effects.

Due to the low prevalence and intensity of occurrence as shown in this study, metacestode infestations do not present marketing problems for most commercially important fish species in the gulf of Guinea. Stromateus fiatola, which is not a particularly valued species, may be excluded from human consumption due to high infestation with Otobothrium sp. The importance of Poecilancistrum caryophyllum in sciaenid fish of the gulf of Guinea might require further evaluation considering the very high infestation rates recorded by Overstreet (1977) in the gulf of Mexico. 


\section{Acknowledgements}

We wish to thank Prof. K. Andersen for her support during the SEM work done at the Electron Microscopical Unit for Biological Science, University of Oslo (Norway). Financial support was provided by the GKSS Forschungszentrum Geesthacht within the framework of the German/Nigerian cooperation and the German Research Council (DFG).

\section{REFERENCES}

Adjei E. L., A. Barnes, R. J. G. Lester, 1986. A method for estimating possible parasite-related host mortality, illustrated using data from Callitetrarhynchus gracilis (Cestoda: Trypanorhyncha) in lizardfish (Saurida spp.). Parasitology, 92, 227-243.

Bane G. W., 1969. Parasites of the yellowfin tuna, Thunnus albacares, in the Atlantic (Pisces: Scombridae). Wasmann J. Biol., 27, 163-175.

Bates R. M., 1990. A checklist of the Trypanorhyncha (Platyhelminthes: Cestoda) of the world (1935-1985). National Museum of Wales, Cardiff, Zool Ser., 1, 218 p.

Baudin-Laurencin F., 1971. Crustacés et Helminthes parasites de l'Albacore (Thunnus albacares) du golf de Guinée - Note préliminaire. Doc. Scient. Cent. Rech. Océanogr. Abidjan, 2, 11-30.

Bussieras J., J. F. Aldrin, 1965. Une tétrarhynche osevasculaire des thons du golf de Guinée due aux larves plerocercus de Dasyrhynchus talismani (R. Ph. Dollfus, 1935). Rev. Elev. Med. vet. Pays trop., 182, 137-143.

Carvajal J., A. Rego, 1985. Critical studies on the genus Callitetrarhynchus (Cestoda: Trypanorhyncha) with recognition of Rhynchobothrium speciosum (Linton, 1897) as a valid species of the genus Callitetrarhynchus. System. Parasitol., 7, 161-167.

Cruz-Reyes A., 1973. Céstodes de peces de Mexico I. Redescriptión del subgénero Otobothrium (Pseudotobothrium) (Dollfus, 1942) y de la especie Otobothrium (P.) dipsacum (Linton, 1807). An. Inst. Biol. Univ. Natl. Autón. México, Ser. Zool. (1), 44, 25-34.

Dollfus R. P., 1942. Etudes critiques sur les Tétrarhynques du Muséum de Paris. Arch. Mus. Hist. nat. Paris, 19, $1-466$.

Dollfus R. P., 1953. Les parasites animaux de la morue Atlanto-Arctique Gadus callarias L. (= morhua L.) et leur distribution géographique. L. Encycl. Biol., 43, 1-423.

Dollfus R. P., 1960. Sur une collection de Tétrarhynques homeacanthes de la famille des Tentaculariidae récoltées principalement dans la région de Dakar. Bull. Inst. fr. Afr. noire, Sér. A, 22, 788-852.

Escalante H., J. Carvajal, 1984. Larval trypanorhynchid cestodes from Peruvian teleost fishes, with descriptions of two new species. Stud. Neotrop. Fauna Environm., 19, 185-194.

Fischer W., J. G. Bianchi, W. B. Scott, 1981. FAO identification sheets for fishery purposes. Eastern Central Atlantic; fishing areas 37, 47 (in part). Canada Fundsin-Trust. Department of Fisheries and Oceans, Ottawa, Canada,1-7.
Grabda J., 1977. Studies on parasitation and consumability of Alaska pollack, Theragra chalcogramma (Pall.). Acta Ichthyol. Piscat., 7, 15-34.

Hemmingsen W., K. MacKenzie, 1993. A checklist of the protozoan and metazoan parasites reported from the Atlantic cod, Gadus morhua. L. Bull. Eur. Ass. Fish Pathol, 13, 134-137.

Hoffmann R., C. R. Kenndy, J. Meder, 1986. Effects of Eubothrium salvelini Schrank, 1790 on arctic charr, Salvelinus alpinus L., in an alpine lake. J. Fish Dis., 9, 153-157.

Klöser H., J. Plötz, H. Palm, A. Bartsch, G. Hubold, 1992. Adjustment of anisakid nematode life cycle to the high Antarctic food web as shown by Contracaecum radiatum and C. osculatum in the Weddell Sea. Antarct. Sci., 4, 171-178.

Linton E., 1897. Notes on larval cestode parasites of fishes. Proc. U. S. Natl. Mus., 19, 787-824.

Lüling K. H., 1951. Neuere Untersuchungen über die Parasiten des Rotbarsches: Sebastes marinus L. Z. Parasitenk., 15, 8-24.

MacKenzie K., 1987. Relationships between the herring, Clupea harengus L., and its parasites. Adv. Mar. Biol., 24, 263-319.

Mattis T. E., 1986. Development of two tetrarhynchidean cestodes from the northern gulf of Mexico. PhD thesis, Univ. South. Mississippi, $172 \mathrm{p}$.

Mehl J. A. P., 1970. Two flesh parasites of barracouda (Teleostei: Gempylidae) from eastern Cook Strait. N. Z. J. mar. Freshw. Res., 3, 241-247.

Nakajima J., S. Egusa, 1972. Studies on a new trypanorhynchan larva, Callitetrarhynchus sp., parasitic on cultured yellowtail. XV. Life-Cycle. Fish Pathol., 7, 6-14.

Obiekezie A. I., K. Anders, R. Lick, H. Möller, H. Palm, 1992. External lesions and flesh parasites in commercial fishes of Nigerian inshore waters. Aquat. Living Resour., 5, 173-183.

Overstreet R. M., 1977. Poecilancistrium caryophyllum and other trypanorhynch cestode plerocercoids from the musculature of Cynoscion nebulosus and other sciaenid fishes in the gulf of Mexico. J. Parasitol., 63, 780-789.

Overstreet R. M., 1978. Trypanorhynch infections in the flesh of sciaenid fishes. Mar. Fish. Rev., 40, 37-38.

Palm H., 1992. Identification and quantification of cestode larvae of fishes from different Atlantic regions. (in German). M. Sc. thesis, Univ. Kiel, 120 p.

Palm H., H. Möller, F. Petersen, 1993. Otobothrium penetrans (Cestoda: Trypanorhyncha) in the flesh of belonid fish from Philippine waters. Int. J. Parasitol., 23, 749-755. 
Pctersen F., H. Palm, H. Möller, M. Cuzi, 1993. Flesh parasites of fish from central Philippine waters. Dis. aquat. Org., 15, 81-86.

Radhakrishnan S., N. B. Nair, N. K. Balasubramanian, 1983. Gymnorhynchus gigas plerocercoid (Cestoda: Gymnorhynchidae) infection of the liver of Diodon hystrix (Pisces: Diodontidae). III. Biochemical composition of infected fish. Acta Ichthyol. Pisc., 13, 141-147.

Reimer I.. W., 1984. Häufig auftretende Helminthenlarven im Fleisch tropischer Fische. V. Wissenschaftliche Konferenz zu Fragen der Physiologie, Biologie und Parasitologie von Nutzfischen, Wilhelm-Piek-Univ, Rostock, 12.-14. Sept. 1983, 82-84.

Richards K. S., C. Arme, 1981. The effect of the plerocercoid larva of the pseudophyllidean cestode Ligula intestinalis on the musculature of the bream (Abramis brama). Z. Parasitenk., 65, 207-215.

Rosen R., T. A. Dick, 1984. Growth and migration of plerocercoids of Triaenophorus crassus Forel and pathology in experimentally infected whitefish Coregonus clupeaformis (Mitchill). Can. J. Zool., 62, 203-211.
Schramm M., 1991. Grillotia perelica (Cestoda: Trypanorhyncha) plerocercoids in mullet (Pisces: Mugilidae) from estuaries in Transkei, Southern Africa. S. Afr. J. Sci., 11, 169-178.

Scott J. S., 1988. Helminth parasites of redfish (Sehastes fasciatus) from the Scotian Shelf, bay of Fundy, and eastern gulf of Maine. Can. J. Zool., C5, 617-621.

Scott J. S., S. A. Bray, 1989. Helminth parasites of the alimentary tract of Atlantic halibut (Hippoglossus hippoglossus L.) and Greenland halibut (Reinhardtius hippoglossoides (Walbaum) on the Scotian Shelf. Can. J. Zool., 67, 1476-1481.

Shuler R. H., 1938. Some cestodes of fish from Tortugas, Florida. Parasitology, 24, 57-63.

Southwell T., 1929. A monograph on cestodes of the order Trypanorhyncha from Ccylon and India. Part I. Ceylon J. Sci., 15, 169-317.

Sprengel G., H. Lüchtenberg, 1991. Infection by endoparasites reduces maximum swimming speed of European smelt Osmerus eperlanus and European eel Anguilla anguilla. Dis. aquat. Org., 11, 31-35. 